\title{
The National After-School Athletics Program Participation as a Tool to Reduce the Risk of Obesity in Adolescents after One Year of Intervention: A Nationwide Study
}

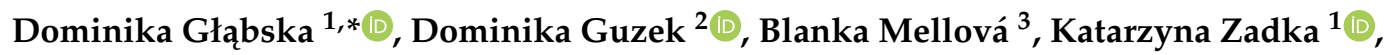 \\ Katarzyna Żywczyk ${ }^{3}$ and Krystyna Gutkowska ${ }^{2}$ \\ 1 Department of Dietetics, Faculty of Human Nutrition and Consumer Sciences, Warsaw University of Life \\ Sciences (SGGW-WULS), 159C Nowoursynowska Street, 02-776 Warsaw, Poland; katarzyna_zadka@sggw.pl \\ 2 Department of Organization and Consumption Economics, Faculty of Human Nutrition and Consumer \\ Sciences, Warsaw University of Life Sciences (SGGW-WULS), 159C Nowoursynowska Street, 02-776 Warsaw, \\ Poland; dominika_guzek@sggw.pl (D.G.); krystyna_gutkowska@sggw.pl (K.G.) \\ 3 Nutrition, Health and Wellness Unit, Nestlé Polska S.A., 32 Domaniewska Street, 02-672 Warsaw, Poland; \\ blanka.mellova@pl.nestle.com (B.M.); katarzyna.zywczyk@pl.nestle.com (K.Ż.) \\ * Correspondence: dominika_glabska@sggw.pl; Tel.: +48-22-593-71-26
}

Received: 27 December 2018; Accepted: 29 January 2019; Published: 31 January 2019

check for updates

\begin{abstract}
Regular exercise during school hours is encouraged; however many children and adolescents fail to meet the recommendations during this time. Extracurricular activities may be a more appealing way for youth to achieve guidelines, and it is recommended that they attend two sessions each week. The aim of the study was to assess the influence of participation in a national physical activity program accompanied by nutritional education for trainers on the risk of obesity and body composition in a nationwide sample of boys and girls, after one year of intervention. The \#goathletics Study was conducted in a group of 1014 adolescents aged 12-13: 507 individuals for the Athletics for All program (210 boys, 297 girls) and 507 pair-matched individuals not participating in any physical activity program (matching including: gender, age, city of residence). The body mass $(\mathrm{kg})$, Body Mass Index (BMI) $\left(\mathrm{kg} / \mathrm{m}^{2}\right)$, waist circumference (WC) $(\mathrm{cm})$, waist-to-height ratio (WHtR) (-) and body composition (\%) (measured using bioelectrical impedance method) were compared in a gender-related sub-groups using $t$-Student test (for parametric distributions) or Mann-Whitney $\mathrm{U}$ test (for nonparametric distributions) and $\mathrm{chi}^{2}$ test (for the share of sub-groups). After one year of intervention, lower body mass percentile, BMI percentile, WC, WHtR and fat mass share, higher muscle mass share, as well as lower frequency of overweight/obesity and abdominal fat distribution were observed both for boys and girls participating in the physical activity intervention compared to the pair-matched controls. The after-school physical activity program accompanied by nutritional education for trainers may be a highly effective method for reducing the risk of obesity both for boys and girls, as regular participation is ensured.
\end{abstract}

Keywords: body mass; waist circumference; body composition; fat mass; muscle mass; physical activity; adolescents; \#goathletics Study

\section{Introduction}

School-based physical activity interventions are indicated as a valuable approach to improve the physical performance [1] and general well-being [2] of children and adolescents, as well as to increase their physical activity enjoyment [3]. However, in a number of studies, the influence of school-based 
physical activity interventions on the body mass of children is not stated [4-6]. Even though an effect on anthropometric measurements is observed in some studies [7-9], it is not always noted. Moreover, in the meta-analysis of randomized trials by Guerra et al. [10], as well as in the meta-analysis by Harris et al. [11], it was observed that school-based interventions had no influence on either body mass or Body Mass Index (BMI) of children and adolescents.

The above-indicated insufficient effect of school-based programs on body mass of children and adolescents may result from their general reluctance to participate in, and avoidance of, school-based physical activity [12]. However, there is also a possibility to implement extracurricular physical activity interventions for children and adolescents that may be superior due to better adherence. In spite of the rather small number of studies analyzing the after-school physical activity interventions published thus far, such a possibility seems to be promising. In the cluster randomized trial of Martínez Vizcaíno et al. [13], it was stated that for primary school children, participation in such programs for a half year may lead to a reduction in adiposity (defined as excessive fat accumulation in adipose tissue) in boys and girls, measured as skin-fold thickness, as well as in girls, measured as a body fat share. Similarly, in a further study of Martínez Vizcaíno et al. [14], it was stated that a reduction of a waist circumference (WC) was also observed for boys and girls, but the prevalence of excessive body mass was not modified by the intervention. The similar result was also observed in the study of Yin et al. [15], in which a reduction in adiposity measured as a body fat share was found after three years of after-school intervention in primary school children. Also, in the study of Salcedo Aguilar et al. [16], it was observed that participation in an extracurricular program for two years led to decrease in the overweight frequency in primary school girls, but not boys. Moreover, in a systematic review and through meta-analysis of quasi-experimental, pilot, non-randomised or randomised trials of Mears \& Jago [17], it was concluded that there is mixed evidence for increasing the physical activity levels by extracurricular physical activity interventions, and the stronger evidence was observed for overweight or obese children than for children with normal body weight. This differentiation between normal and excessive body weight adolescents is crucial, as for a normal body weight ones, the body mass reduction is not advisable, while for excessive body weight ones, the body mass reduction resulting from adiposity reduction should be obtained.

Regarding after-school physical activity programs, it must be emphasized that the studies conducted thus far have assessed various types and methodologies of interventions which influenced the observed results. The review of reviews by Demetriou et al. [18] indicated that a higher effectiveness is stated for programs conducted in school settings than for those conducted in community settings, for programs including two or more sessions a week than for those including less number of sessions, and for programs guaranteeing regular participation than for those not ensuring it. Moreover, the indicated review confirmed the observations of Salcedo Aguilar et al. [16]; that is, better results are observed for girls than boys when the intervention is associated with body weight control.

At the same time, in order to increase the effectiveness of the programs, it was proven to be more effective to include in educational programs not only physical activity, but also nutritional elements [19]. Such an approach is in accordance with the general strategy of the World Health Organization (WHO), indicating, as a major aim to achieve, the necessity of effective health programs conducted in school settings combining physical activity and dietary intervention [20]. Due to the fact that the main factor contributing to excessive body mass is an energy intake that exceeds energy expenditure [21], both actions, i.e., decreasing energy intake and increasing energy expenditure, may be effective. In spite of the fact that in some studies, physical activity is stated to be a more important determinant of the body mass of adolescents than dietary behaviors [22], the role of both is emphasized, referring to them as the "Big Two" [23].

As the influence of trainers, as prominent adult social leaders, is observed to cause positive changes to the eating behaviors of children [24], the other concept is to not influence participants directly, but to educate trainers to influence participants indirectly. Taking into account the promising role of extracurricular physical activity interventions, the aim of the present study was to assess the 
influence of participation in a national after-school athletics program (conducted in school settings, three sessions a week, ensuring regular participation and including nutritional education of trainers) on the risk of obesity and body composition in a nationwide sample of boys and girls after one year of intervention.

\section{Materials and Methods}

\subsection{Ethics Statement}

The \#goathletics Study was conducted at the Department of Dietetics, Warsaw University of Life Sciences (WULS-SGGW). It was conducted according to the guidelines laid down in the Declaration of Helsinki. All procedures involving human subjects were approved by the Ethics Committee of the Faculty of Human Nutrition and Consumer Sciences of the Warsaw University of Life Sciences in Warsaw, Poland (No. 16/2017; 19.06.2017). Written informed consent was provided by all participants and their parents or legal guardians.

\subsection{Intervention}

The \#goathletics Study was conducted in two groups of adolescents, aged 12-13. The study group included 507 individuals representative of Athletics for All (in Polish Lekkoatletyka Dla Każdego-LDK), which is a nationwide after-school physical activity program, and the control group included 507 pair-matched individuals recruited from a general population but not participating in any physical activity program.

The Athletics for All program (http:/ / www.lekkoatletykadlakazdego.pl/), an after-school physical activity program which is free of charge, has been conducted in Poland since 2014. It is organized by the Polish Athletic Association and supported by the Ministry of Sport and Tourism and Nestlé Polska S.A. It is a real life intervention already implemented in all the regions of Poland, both in big cities and small towns in 807 training groups. Since 2014, over 300,000 children and adolescents from 1244 primary and secondary schools have participated in the program. The program was implemented with the aim of increasing physical activity in a group of primary school children and adolescents by providing regular athletics training.

In the current school year, in all the regions of Poland, there are 180,000 participants of the program (majority of them in the youngest age groups); almost 8000 primary school adolescents aged 12-13 participate. The regular attendance in the school year is ensured due to the fact that the program is free of charge and regular participation is a necessary condition (it is controlled for each session and recorded by trainer using a dedicated electronic application). Such an obligation guarantees the low dropout level that, in the group of adolescents aged 12-13, is currently $10 \%$ on an annual basis (based on the data for $2017 / 2018$ school year).

As a part of the program, physical activity education session and athletics training are conducted in schools in various locations of Poland, while for a group of participating adolescents, three sessions a week are conducted (each session of a 90 min of moderate to high intensity physical activity) in which regular participation is required. Each trainer receives the identical outlines of the trainings with the specified aim of each training, necessary equipment and detailed instructions for all the elements of training. All the trainings are planned by the trainers from the Polish Athletic Association and are aimed at creating necessary abilities and skills for the athletics disciplines.

An additional nutritional education session was conducted for trainers at the beginning of the Athletics for All program, and it is repeated each year; during this session, additional educational materials are provided, and trainers are obliged to teach their participants not only about physical activity but also about proper balanced diet.

The additional element of the Athletics for All program that increased its attractiveness are the athletics events organized exclusively for its participants. In such events, including regular school cups, regional cups and a national cup, professional athletes and even star athletes (national and international 
champions) take part. So far, 2400 school cups and 300 regional cups have been organized, while the national cup is organized each year. Star athletes have contact with the Athletics for All program participants, meeting them, training together, and contacting them via a dedicated social network.

\subsection{Study Groups and Design}

\subsubsection{Participants}

The \#goathletics Study aimed to evaluate the effectiveness of the Athletics for All program, not only by the assessment of anthropometric measurements, but also by the assessment of physical performance and nutritional behavior [25]. For this study, the study groups were recruited following a two-stage recruitment procedure, in which adolescents aged 12-13 from all the regions of Poland (central, north, north-west, south-west, south, east) were included.

For the study group, the first stage of the recruitment procedure involved a random selection of primary schools in which the Athletics for All after-school physical activity program is being conducted. The geographical distribution of schools was based on Polish statistical data, and both big cities and small towns were included in the selection (random purposive sampling).

The second stage of recruitment of the study group involved a random selection of participants in the Athletics for All program from each school $(n=600)$. The proportion of boys and girls selected was required to be in accordance with the general proportion of participants of the Athletics for All program (with a higher share of girls) (random sampling). Afterwards, the individuals meeting the inclusion criteria (Figure 1) were pair-matched with the control ones.

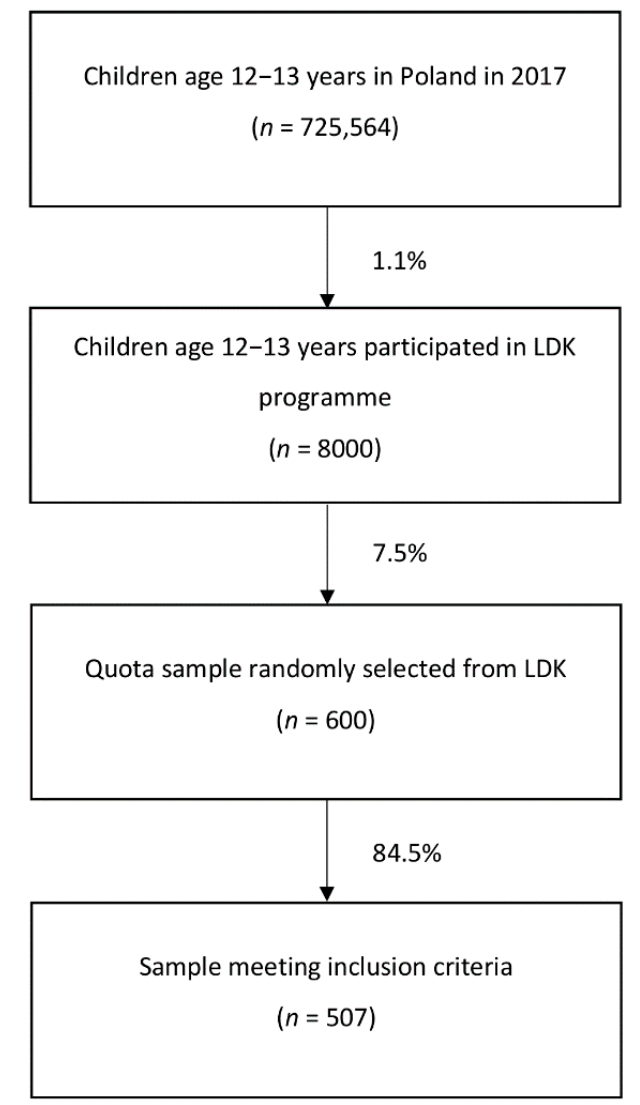

Figure 1. The selection of participants for the Athletics for All program, based on Statistical Demography Yearbook for 2017 [26]. 
For the control group, the first stage of the recruitment procedure involved the selection of primary schools in which Athletics for All after-school physical activity program was not being conducted. The schools were required to be located in the same cities as schools chosen to recruit the study group, and so both big cities and small towns were included (purposive sampling).

The second stage of recruitment of the control group involved a random selection of adolescents who were neither participants in the Athletics for All program nor participants of any other physical activity program. The pair-matching procedure was applied, and the variables used for matching included gender, age, and city of residence. During this stage, the individuals eligible for recruitment, after being pair-matched with study individuals, were first identified, and then for each study individual, one pair-matched control individual was randomly chosen (pair-matched random sampling).

The inclusion criteria for the studied group were as follows:

- Caucasian,

- $\quad$ adolescents aged 12-13,

- participating for at least 1 year in the Athletics for All program training sessions regularly (three sessions a week),

- participating in any other physical activity program neither at school, nor after school,

- consent agreement of adolescents for participation,

- consent agreement of the parents/legal guardians for the participation of their children.

The exclusion criteria for the studied group were as follows:

- $\quad$ any data missing,

- diagnosed disabilities in cognitive or motor functions,

- pacemakers and other stimulators (forefending against bioelectrical impedance measurement),

- $\quad$ diagnosed with epilepsy (forefending against bioelectrical impedance measurement).

The inclusion criteria for the control group were as follows:

- Caucasian,

- $\quad$ adolescents aged 12-13,

- $\quad$ participating in the Athletics for All program neither currently, nor in the past,

- participating in any other physical activity program neither at school, nor after school,

- consent agreement of adolescents for participation,

- consent agreement of the parents/legal guardians for the participation of their children.

The exclusion criteria for the control group were as follows:

- $\quad$ any data missing,

- diagnosed disabilities in cognitive or motor functions,

- pacemakers and other stimulators (forefending against bioelectrical impedance measurement),

- $\quad$ diagnosed with epilepsy (forefending against bioelectrical impedance measurement).

The group of Caucasian adolescents was chosen as typical for the Polish population, i.e., a homogenous Caucasian one [27]; similar to a number of studies conducted for Polish population, such an inclusion criterion was applied [28,29].

In spite of the fact that in the systematic review of Bacil et al. [30] there is an association between biological maturation and physical activity, the maturation of the participating girls was not assessed to reduce the stress and embarrassment of adolescents, as well as to respect privacy and confidentiality [31]. It also resulted from the fact that an interaction of fat mass with maturation is often not observed [32].

At the end of the procedure, there were a total of 1014 adolescents (507 individuals representative of the Athletics for All program, including 210 boys and 297 girls, and 507 pair-matched individuals not 
participating in any physical activity program including 210 boys and 297 girls) recruited for the study. The geographical distribution of the participants is presented in Figure 2.

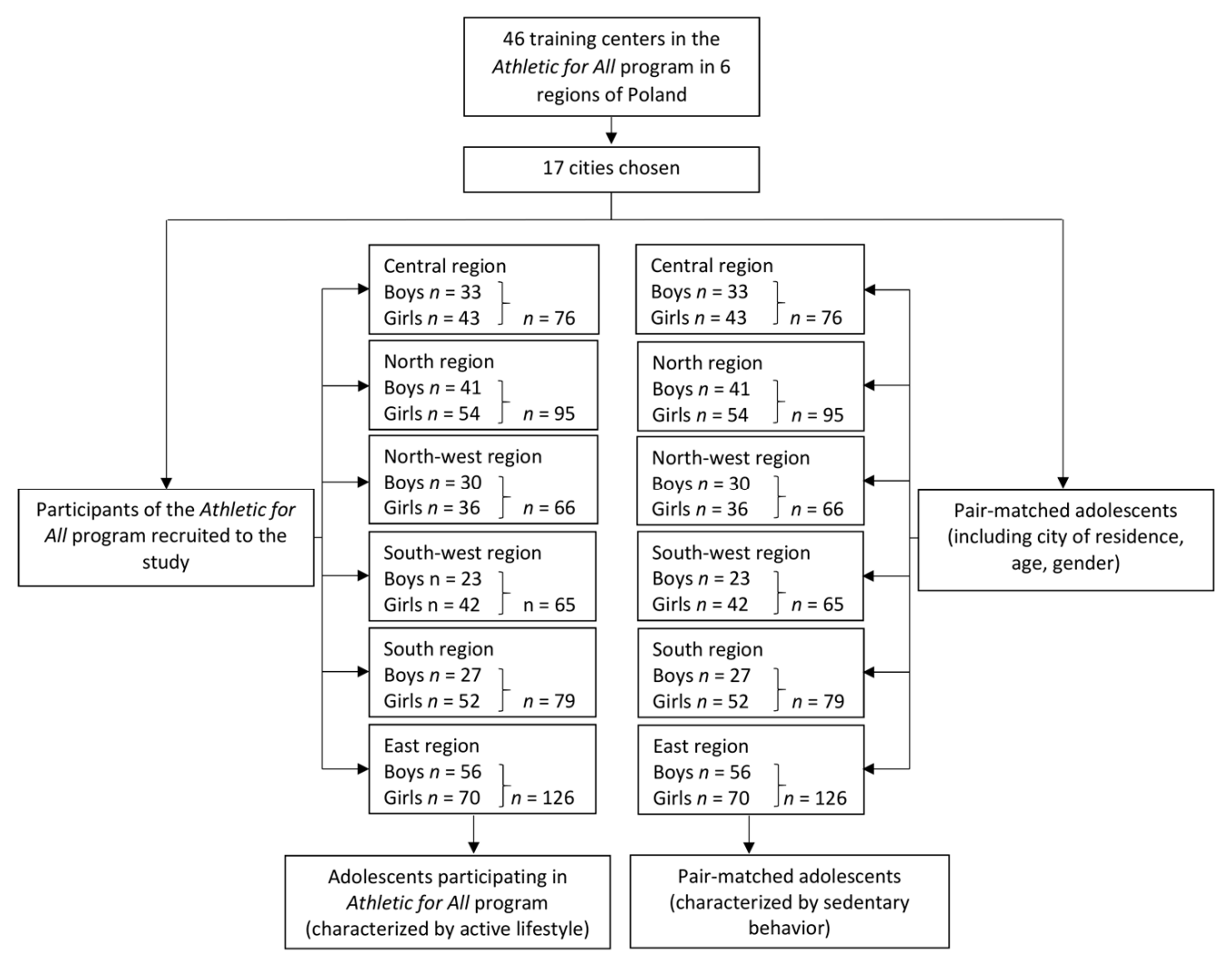

Figure 2. The geographical breakdown of the participants of the \#goathletics Study.

\subsubsection{Assessment of the Body Mass, Height, and BMI of the Study Participants}

The body mass and height were measured by a professional dietitian, according to the widely accepted and applied rules [33], using a calibrated weighing scale (accuracy $\pm 0.1 \mathrm{~kg}$ ) and a stadiometer (accuracy $\pm 0.5 \mathrm{~cm}$ ). The BMI was calculated based on the Quetelet equation (body mass $(\mathrm{kg}) /$ height $\left.^{2}\left(\mathrm{~m}^{2}\right)\right)$.

Following measurements, the obtained values were assessed on the basis of the Polish growth reference values. The body mass percentile, the height percentile and the BMI percentile of each participant were specified by gender and age [34] using the OLAF software [35].

Additionally, the BMI was interpreted according to the growth reference cutoffs for school-aged children and adolescents of the WHO [36], which are commonly applied [37]. BMI values were interpreted as follows: malnutrition-BMI $<5$ th percentile; normal weight-BMI $E<5$ th-85th percentile); overweight-BMI $E<85$ th-95th percentile); or obesity-BMI $\geq 95$ th percentile. The BMI percentile was assessed by gender and age on the basis of the Polish growth reference values [34].

The BMI percentile of the studied group stratified by region is presented in Table 1. 
Table 1. The BMI percentile of adolescents participating in a national athletics program and pair-matched control group of adolescents stratified by region.

\begin{tabular}{lcccc}
\hline \multirow{2}{*}{ Region } & $\begin{array}{c}\text { Individuals Participating in a National } \\
\text { Athletics Program }\end{array}$ & \multicolumn{2}{c}{$\begin{array}{c}\text { Individuals Non-Participating in a } \\
\text { National Athletics Program }\end{array}$} \\
\cline { 2 - 5 } & Mean \pm SD & $\begin{array}{c}\text { Median } \\
\text { (Minimum-Maximum) }\end{array}$ & Mean \pm SD & $\begin{array}{c}\text { Median } \\
\text { (Minimum-Maximum) }\end{array}$ \\
\hline Central region $(n=76)$ & $45.8 \pm 24.2$ & $\begin{array}{c}44.0^{*} \\
(1.0-94.0)\end{array}$ & $59.0 \pm 29.5$ & $\begin{array}{c}67.5^{*} \\
(3.0-99.9)\end{array}$ \\
\hline North region $(n=95)$ & $52.9 \pm 25.8$ & $\begin{array}{c}53.0 \\
(1.0-99.0)\end{array}$ & $60.5 \pm 28.0$ & $\begin{array}{c}63.0^{*} \\
(1.0-99.0)\end{array}$ \\
\hline North-west region $(n=66)$ & $48.1 \pm 26.2$ & $\begin{array}{c}49.5^{*} \\
(3.0-93.0)\end{array}$ & $57.8 \pm 28.7$ & $\begin{array}{c}65.0^{*} \\
(1.0-99.0)\end{array}$ \\
\hline South-west region $(n=65)$ & $48.7 \pm 28.1$ & $\begin{array}{c}52.0^{*} \\
(2.0-97.0)\end{array}$ & $63.2 \pm 28.6$ & $\begin{array}{c}62.0^{*} \\
(4.0-99.0)\end{array}$ \\
\hline South region $(n=79)$ & $43.7 \pm 27.0$ & $\begin{array}{c}40.0^{*} \\
(1.0-99.9)\end{array}$ & $63.2 \pm 30.5$ & $\begin{array}{c}70.0^{*} \\
(0.1-99.0)\end{array}$ \\
\hline East region $(n=126)$ & $47.7 \pm 25.7$ & $\begin{array}{c}47.5^{*} \\
(1.0-98.0)\end{array}$ & $51.6 \pm 28.8$ & $\begin{array}{c}4.5 \\
(1.0-98.0)\end{array}$ \\
\hline
\end{tabular}

${ }^{*}$ Nonparametric distribution (verified using Shapiro-Wilk test; $p \leq 0.05$ ).

\subsubsection{Assessment of the WC and Waist-to-Height Ratio (WHtR) of the Study Participants}

WC was measured by a professional dietitian, using a nonelastic flexible measuring tape (accuracy $\pm 0.5 \mathrm{~cm}$ ). According to the widely accepted and applied rules, which were defined by the WHO [38] and International Diabetes Federation (IDF) [39], the mid-abdominal WC was measured in the horizontal plane midway between the lowest ribs and the iliac crest [40]. Following the measurement, the obtained values were assessed on the basis of the Polish growth reference values [41]. The individual WC values were compared with the 90th percentile value by gender and age, and the WC values were interpreted as follows: abdominal fat distribution-WC $\geq 90$ th percentile; or no abdominal fat distribution-WC $<90$ th percentile [42].

On the basis of the previously obtained measurements of body height and WC, the WHtR was calculated by dividing WC by height (waist $(\mathrm{cm}) /$ height $(\mathrm{cm})$ ) [43]. The WHtR values were interpreted as follows: central fatness-WHtR $>0.500$; or no central fatness $-W H t R \leq 0.500$ [44].

\subsubsection{Assessment of the Body Composition of the Study Participants}

The body composition was assessed using bioelectrical impedance analysis. The measurements were taken by a professional dietitian using BIA 101/ASE (Akern Srl, Firenze, Italy). According to the commonly-applied rules, the measurements were obtained in the morning, in the fasting state (the last meal was to be consumed and the last beverage was to be drunk at least $8 \mathrm{~h}$ before the measurement), after a day when no excessive physical activity was performed; that is, no training was conducted on the previous day [45]. The measurements were taken after removing shoes and jewelry, and when the participants were in light underwear or sportswear with no metal elements.

The participants were asked to lie down on a two-layer polyurethane foam matte with no metal or conductive elements, and after $5 \mathrm{~min}$ of resting, measurements were recorded in a supine recumbent position according to the recommendations [46]. Before taking measurements, the dorsal surface of the right hand and right feet with no skin lesions were rubbed using medical disinfection cotton pads. The surface was allowed to dry, and two standard Ag-AgCl rectangular electrodes (Pro-Tab, PT 2334, Bio Protech, contact area higher than $4 \mathrm{~cm}^{2}$ ) were placed (with distance between the electrodes being at least $5 \mathrm{~cm}$ ) for taking measurement in a tetrapolar electrode configuration. The measurements were conducted with arms separated from the trunk by about $30^{\circ}$ and with legs separated by about $45^{\circ}$ [47].

During the measurement, the data of resistance and reactance at a frequency of $50 \mathrm{kHz}$ were recorded, while they remained stable. Following measurement, the Bodygram 1.31 software (Akern Srl, 
Firenze, Italy) and its equations were applied to calculate body cell mass (content, $\%$ of body mass, and body cell mass index), fat-free mass (content and \% of body mass), fat mass (content and \% of body mass), total body water (content, $\%$ of body mass, and $\mathrm{Na} / \mathrm{K}$ ratio), extracellular water (content and $\%$ of water content), intracellular water (content and \% of water content), and muscle mass (content and $\%$ of body mass).

\subsection{Statistical Analysis}

The obtained data were analyzed using Shapiro-Wilk test to assess the distribution. Afterwards, due to nonparametric distributions, the sub-groups were compared using Mann-Whitney U test (for nonparametric distributions of continuous variables) or $t$-Student test (for parametric distributions of continuous variables). The categorical variables were compared using a chi ${ }^{2}$ test. A level of significance of $p \leq 0.05$ was accepted. The statistical analysis was conducted using Statistica, version 8.0 (Statsoft Inc., Tulsa, OK, USA) and Statgraphics Plus for Windows 4.0 (Statgraphics Technologies Inc., The Plains, VA, USA).

\section{Results}

\subsection{Basic Anthropometric Characteristics}

The basic anthropometric characteristics of the boys in the study group participating in a national athletics program and boys in the pair-matched control group are presented in Table 2. It can be noted that both body mass and BMI percentile differed significantly between the groups; for boys participating in a national athletics program, lower values of body mass and BMI percentile were observed compared to the control group of boys. Similarly, lower values of WC and WHtR were observed for the participants of national athletics program compared to the control group of boys.

Table 2. The basic anthropometric characteristics of group of boys participating in a national athletics program and pair-matched control group of boys.

\begin{tabular}{|c|c|c|c|c|c|}
\hline \multirow{2}{*}{$\begin{array}{c}\text { The Assessed } \\
\text { Parameters }\end{array}$} & \multicolumn{2}{|c|}{$\begin{array}{l}\text { Boys Participating in a National } \\
\text { Athletics Program }(n=210)\end{array}$} & \multicolumn{2}{|c|}{$\begin{array}{l}\text { Boys Non-Participating in a National } \\
\text { Athletics Program }(n=210)\end{array}$} & \multirow[b]{2}{*}{$p$-Value $* *$} \\
\hline & Mean \pm SD & $\begin{array}{c}\text { Median } \\
\text { (Minimum-Maximum) }\end{array}$ & Mean \pm SD & $\begin{array}{c}\text { Median } \\
\text { (Minimum-Maximum) }\end{array}$ & \\
\hline Body mass (kg) & $47.18 \pm 10.96$ & $\begin{array}{c}46.00 * \\
(25.70-120.00)\end{array}$ & $50.16 \pm 13.84$ & $\begin{array}{c}48.70 * \\
(26.50-144.00)\end{array}$ & 0.0330 \\
\hline $\begin{array}{c}\text { Body mass } \\
\text { percentile (-) }\end{array}$ & $50.71 \pm 26.89$ & $\begin{array}{c}51.00 * \\
(2.00-99.90)\end{array}$ & $57.40 \pm 28.70$ & $\begin{array}{c}59.00 * \\
(1.00-99.0)\end{array}$ & 0.0084 \\
\hline Body height $(\mathrm{cm})$ & $158.69 \pm 10.27$ & $\begin{array}{c}157.50 \\
(133.20-187.00)\end{array}$ & $157.72 \pm 9.68$ & $\begin{array}{c}156.65 * \\
(137.00-180.00)\end{array}$ & 0.3301 \\
\hline $\begin{array}{l}\text { Body height } \\
\text { percentile (-) }\end{array}$ & $57.45 \pm 29.59$ & $\begin{array}{c}59.00 * \\
(1.00-99.90)\end{array}$ & $54.86 \pm 29.26$ & $\begin{array}{c}54.00 * \\
(1.00-99.00)\end{array}$ & 0.4268 \\
\hline BMI $\left(\mathrm{kg} / \mathrm{m}^{2}\right)$ & $18.59 \pm 2.80$ & $\begin{array}{c}18.10 * \\
(14.00-34.30)\end{array}$ & $19.80 \pm 3.76$ & $\begin{array}{c}19.20 * \\
(14.00-35.50)\end{array}$ & 0.0003 \\
\hline BMI percentile (-) & $47.06 \pm 25.83$ & $\begin{array}{c}45.50 * \\
(2.00-99.00)\end{array}$ & $57.13 \pm 29.70$ & $\begin{array}{c}60.00 * \\
(1.00-99.00)\end{array}$ & 0.0001 \\
\hline $\mathrm{WC}(\mathrm{cm})$ & $68.85 \pm 8.59$ & $\begin{array}{c}68.00 * \\
(30.50-111.00)\end{array}$ & $73.28 \pm 12.03$ & $\begin{array}{c}72.00 * \\
(51.00-140.00)\end{array}$ & 0.0002 \\
\hline WHtR (-) & $0.43 \pm 0.05$ & $\begin{array}{c}0.42 * \\
(0.20-0.68)\end{array}$ & $0.46 \pm 0.07$ & $\begin{array}{c}0.45^{*} \\
(0.32-0.78)\end{array}$ & $<0.0001$ \\
\hline
\end{tabular}

BMI—Body Mass Index; WC—Waist Circumference; WHtR-Waist-to-Height Ratio; ${ }^{*}$ nonparametric distribution (verified using Shapiro-Wilk test; $p \leq 0.05$ ); ${ }^{* *}$ compared using $t$-Student test (for parametric distribution) and Mann-Whitney U test (for nonparametric distribution).

The basic anthropometric characteristics of the girls in the study group participating in a national athletics program and girls in the pair-matched control group are presented in Table 3. It can be 
noted that both body mass and BMI percentile differed significantly between the groups; for girls participating in a national athletics program, lower values of body mass and BMI percentile and higher values of body height percentile were observed compared to the control group of girls. Similarly, lower values of WC and WHtR were observed for the participants of national athletics program compared to the control group of girls.

Table 3. The basic anthropometric characteristics of group of girls participating in a national athletics program and pair-matched control group of girls.

\begin{tabular}{|c|c|c|c|c|c|}
\hline \multirow{2}{*}{$\begin{array}{c}\text { The Assessed } \\
\text { Parameters }\end{array}$} & \multicolumn{2}{|c|}{$\begin{array}{l}\text { Girls Participating in a National } \\
\text { Athletics Program }(n=297)\end{array}$} & \multicolumn{2}{|c|}{$\begin{array}{l}\text { Girls Non-Participating in a National } \\
\text { Athletics Program }(n=297)\end{array}$} & \multirow[t]{2}{*}{$p$-Value $* *$} \\
\hline & Mean \pm SD & $\begin{array}{c}\text { Median } \\
\text { (Minimum-Maximum) }\end{array}$ & Mean \pm SD & $\begin{array}{c}\text { Median } \\
\text { (Minimum-Maximum) }\end{array}$ & \\
\hline Body mass (kg) & $47.31 \pm 9.66$ & $\begin{array}{c}47.30 * \\
(25.50-87.90)\end{array}$ & $48.97 \pm 11.23$ & $\begin{array}{c}48.20 * \\
(23.50-88.00)\end{array}$ & 0.1146 \\
\hline $\begin{array}{l}\text { Body mass } \\
\text { percentile }(-)\end{array}$ & $51.44 \pm 26.90$ & $\begin{array}{c}53.00 * \\
(0.10-99.90)\end{array}$ & $57.09 \pm 29.18$ & $\begin{array}{c}58.00 * \\
(0.10-99.90)\end{array}$ & 0.0117 \\
\hline Body height (cm) & $157.99 \pm 7.94$ & $\begin{array}{c}159.00 * \\
(132.40-176.50)\end{array}$ & $155.54 \pm 8.23$ & $\begin{array}{c}155.90 \\
(132.50-175.70)\end{array}$ & 0.0001 \\
\hline $\begin{array}{l}\text { Body height } \\
\text { percentile (-) }\end{array}$ & $55.91 \pm 28.17$ & $\begin{array}{c}60.00 * \\
(0.10-99.00)\end{array}$ & $49.29 \pm 29.12$ & $\begin{array}{c}50.00 * \\
(0.10-99.90)\end{array}$ & 0.0035 \\
\hline BMI $\left(\mathrm{kg} / \mathrm{m}^{2}\right)$ & $18.62 \pm 2.63$ & $\begin{array}{c}18.20 * \\
(12.90-33.30)\end{array}$ & $20.06 \pm 3.64$ & $\begin{array}{c}19.40 * \\
(12.80-32.50)\end{array}$ & $<0.0001$ \\
\hline BMI percentile (-) & $48.60 \pm 26.36$ & $\begin{array}{c}48.00 * \\
(1.00-99.90)\end{array}$ & $59.42 \pm 28.80$ & $\begin{array}{c}63.00 * \\
(0.10-99.90)\end{array}$ & $<0.0001$ \\
\hline $\mathrm{WC}(\mathrm{cm})$ & $66.58 \pm 7.06$ & $\begin{array}{c}66.00 * \\
(48.00-102.00)\end{array}$ & $70.03 \pm 9.66$ & $\begin{array}{c}69.00 * \\
(50.90-106.00)\end{array}$ & $<0.0001$ \\
\hline WHtR (-) & $0.42 \pm 0.04$ & $\begin{array}{c}0.42 * \\
(0.33-0.63)\end{array}$ & $0.45 \pm 0.06$ & $\begin{array}{c}0.44 * \\
(0.32-0.64)\end{array}$ & $<0.0001$ \\
\hline
\end{tabular}

BMI-Body Mass Index; WC-Waist Circumference; WHtR-Waist-to-Height Ratio; * nonparametric distribution (verified using Shapiro-Wilk test; $p \leq 0.05$ ); ${ }^{* *}$ compared using $t$-Student test (for parametric distribution) and Mann-Whitney U test (for nonparametric distribution).

\subsection{Assessment of Body Mass and Abdominal Fat Distribution}

The body mass and abdominal fat distribution of the boys in the study group participating in a national athletics program and boys in the pair-matched control group are presented in Table 4 . It can be noted that among the group of boys participating in a national athletics program, there was a significantly higher proportion of individuals with normal body mass and a significantly lower proportion of individuals with an excessive body mass $(7.6 \%$ vs. $27.6 \%)$ compared to the control group of boys. Similarly, with respect to WC and WHtR, a higher frequency of abdominal fat distribution/central fatness was found in the control group of boys compared to the participants of national athletics program. 
Table 4. The assessment of body mass and abdominal fat distribution in group of boys participating in a national athletics program and pair-matched control group of boys.

\begin{tabular}{|c|c|c|c|c|}
\hline & Assessed Parameters & $\begin{array}{l}\text { Boys Participating in } \\
\text { a National Athletics }\end{array}$ & $\begin{array}{l}\text { Boys Non-Participating } \\
\text { in a National Athletics }\end{array}$ & $p$-Value * \\
\hline \multirow{4}{*}{ BMI } & Malnutrition & $6(2.86 \%)$ & $10(4.76 \%)$ & \multirow{4}{*}{$<0.0001$} \\
\hline & Normal body mass & $188(89.52 \%)$ & $142(67.62 \%)$ & \\
\hline & Overweight & $12(5.71 \%)$ & $39(18.57 \%)$ & \\
\hline & Obesity & $4(1.90 \%)$ & $19(9.05 \%)$ & \\
\hline \multirow{2}{*}{ WC } & No abdominal fat distribution & $183(87.14 \%)$ & $143(68.10 \%)$ & \multirow{2}{*}{$<0.0001$} \\
\hline & Abdominal fat distribution & $27(12.86 \%)$ & $67(31.90 \%)$ & \\
\hline \multirow{2}{*}{ WHtR } & No central fatness & $190(90.48 \%)$ & $156(74.29 \%)$ & \multirow{2}{*}{$<0.0001$} \\
\hline & Central fatness & $20(9.52 \%)$ & $54(25.71 \%)$ & \\
\hline
\end{tabular}

BMI—Body Mass Index; WC—Waist Circumference; WHtR-Waist-to-Height Ratio; ${ }^{*}$ compared using chi ${ }^{2}$ test.

The body mass and abdominal fat distribution of the girls in the study group participating in a national athletics program and girls in the pair-matched control group are presented in Table 5. It can be noted that among the group of girls participating in a national athletics program, there was a significantly higher proportion of individuals with normal body mass and a significantly lower proportion of individuals with an excessive body mass $(10.1 \%$ vs. $26.9 \%)$ compared to the control group of girls. Similarly, with respect to WC and WHtR, a higher frequency of abdominal fat distribution/central fatness was found in the control group of girls compared to the participants of national athletics program.

Table 5. The assessment of body mass and abdominal fat distribution in group of girls participating in a national athletics program and pair-matched control group of girls.

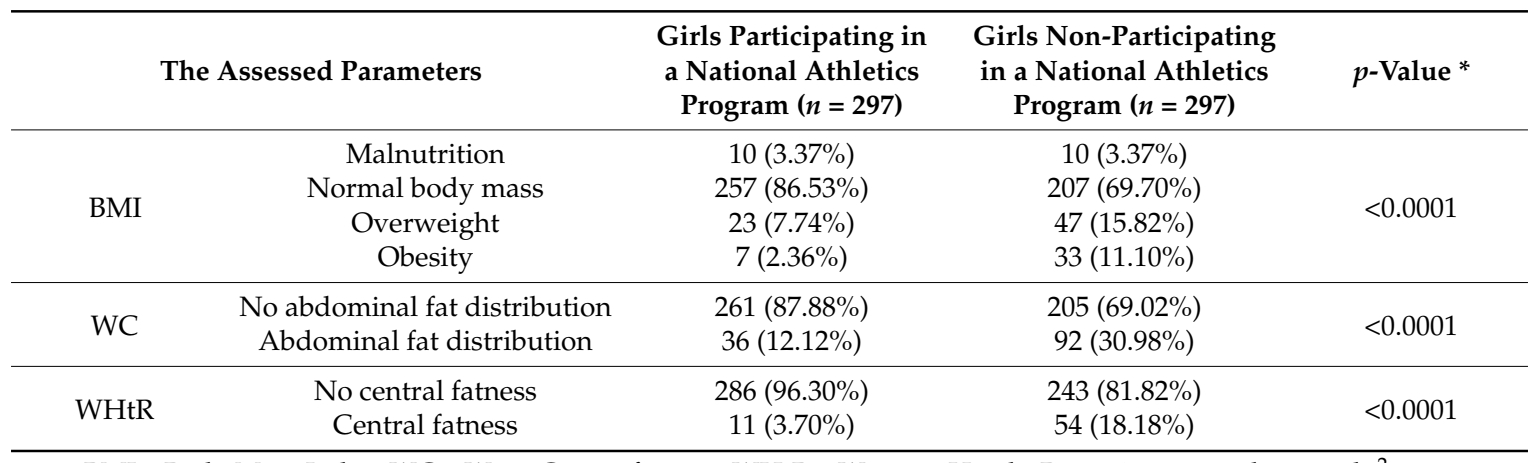

BMI—Body Mass Index; WC—Waist Circumference; WHtR—Waist-to-Height Ratio; ${ }^{*}$ compared using chi ${ }^{2}$ test.

\subsection{Body Composition}

The body composition of the boys in the study group participating in a national athletics program and boys in the pair-matched control group are presented in Table 6. It can be noted that significantly higher values of body cell mass share, fat-free mass share, total body water share, extracellular water share, and muscle mass share were observed in the boys participating in a national athletics program compared to the control group of boys. Simultaneously, significantly lower values of fat mass share and intracellular water share were found in the participants of national athletics program than the control group of boys. 
Table 6. The body composition in group of boys participating in a national athletics program and pair-matched control group of boys.

\begin{tabular}{|c|c|c|c|c|c|}
\hline \multirow[t]{2}{*}{$\begin{array}{l}\text { The Assessed } \\
\text { Parameters }\end{array}$} & \multicolumn{2}{|c|}{$\begin{array}{l}\text { Boys Participating in a National } \\
\text { Athletics Program }(n=210)\end{array}$} & \multicolumn{2}{|c|}{$\begin{array}{l}\text { Boys Non-Participating in a National } \\
\text { Athletics Program }(n=210)\end{array}$} & \multirow{2}{*}{$p$-Value ** } \\
\hline & Mean \pm SD & $\begin{array}{c}\text { Median } \\
\text { (Minimum-Maximum) }\end{array}$ & Mean \pm SD & $\begin{array}{l}\text { Median } \\
\text { (Minimum-Maximum) }\end{array}$ & \\
\hline Body cell mass (kg) & $19.50 \pm 4.58$ & $\begin{array}{c}19.10^{*} \\
(8.90-35.70)\end{array}$ & $19.40 \pm 4.91$ & $\begin{array}{c}18.55^{*} \\
(10.90-43.50)\end{array}$ & 0.6416 \\
\hline Body cell mass (\%) & $52.05 \pm 4.27$ & $\begin{array}{c}52.40 * \\
(8.20-60.20)\end{array}$ & $51.83 \pm 4.01$ & $\begin{array}{c}51.80 * \\
(42.80-87.70)\end{array}$ & 0.0055 \\
\hline $\begin{array}{l}\text { Body cell mass index } \\
\qquad\left(\mathrm{kg} / \mathrm{m}^{2}\right)\end{array}$ & $7.67 \pm 1.08$ & $\begin{array}{c}7.70 \\
(4.50-10.80)\end{array}$ & $7.74 \pm 1.36$ & $\begin{array}{c}7.65^{*} \\
(5.40-15.50)\end{array}$ & 0.8992 \\
\hline Fat-free mass (kg) & $37.17 \pm 7.87$ & $\begin{array}{c}36.70 * \\
(18.80-68.50)\end{array}$ & $37.42 \pm 8.33$ & $\begin{array}{c}36.15^{*} \\
(21.20-79.70)\end{array}$ & 0.9132 \\
\hline Fat-free mass (\%) & $79.15 \pm 6.41$ & $\begin{array}{c}79.90 * \\
(55.70-91.90)\end{array}$ & $75.64 \pm 7.40$ & $\begin{array}{c}76.00 \\
(55.30-99.30)\end{array}$ & 0.0000 \\
\hline Fat mass (kg) & $10.05 \pm 5.05$ & $\begin{array}{c}9.20 * \\
(3.10-51.50)\end{array}$ & $12.96 \pm 7.42$ & $\begin{array}{c}11.75 * \\
(0.20-64.30)\end{array}$ & $<0.0001$ \\
\hline Fat mass (\%) & $20.85 \pm 6.41$ & $\begin{array}{c}20.10^{*} \\
(8.10-44.30)\end{array}$ & $24.63 \pm 8.24$ & $\begin{array}{c}24.25^{*} \\
(0.70-77.10)\end{array}$ & $<0.0001$ \\
\hline Total body water (kg) & $30.62 \pm 5.11$ & $\begin{array}{c}30.50 \\
(14.50-49.60) \\
\end{array}$ & $30.62 \pm 5.29$ & $\begin{array}{c}30.00 * \\
(13.90-56.30)\end{array}$ & 0.7692 \\
\hline Total body water (\%) & $65.55 \pm 7.45$ & $\begin{array}{c}66.20 * \\
(7.90-81.00)\end{array}$ & $62.84 \pm 8.21$ & $\begin{array}{c}62.75 * \\
(22.90-86.70) \\
\end{array}$ & 0.0001 \\
\hline $\mathrm{Na} / \mathrm{K}$ ratio $(-)$ & $1.13 \pm 0.14$ & $\begin{array}{c}1.10 * \\
(0.40-2.00)\end{array}$ & $1.10 \pm 0.13$ & $\begin{array}{c}1.10 * \\
(0.70-1.50)\end{array}$ & 0.0640 \\
\hline Extracellular water $(\mathrm{kg})$ & $12.76 \pm 2.86$ & $\begin{array}{c}12.30 * \\
(7.00-20.80)\end{array}$ & $12.60 \pm 3.23$ & $\begin{array}{c}11.90 * \\
(6.70-36.70)\end{array}$ & 0.3852 \\
\hline Extracellular water (\%) & $41.17 \pm 3.73$ & $\begin{array}{c}41.40 * \\
(10.30-50.00) \\
\end{array}$ & $40.39 \pm 3.19$ & $\begin{array}{c}40.00 * \\
(32.20-60.50) \\
\end{array}$ & 0.0021 \\
\hline Intracellular water (kg) & $17.86 \pm 2.45$ & $\begin{array}{c}17.80 * \\
(7.50-29.80)\end{array}$ & $18.33 \pm 2.69$ & $\begin{array}{c}18.00 * \\
(11.60-34.00)\end{array}$ & 0.2453 \\
\hline Intracellular water (\%) & $58.68 \pm 3.14$ & $\begin{array}{c}58.60 * \\
(50.00-65.90) \\
\end{array}$ & $59.66 \pm 3.07$ & $\begin{array}{c}60.00 * \\
(45.80-67.80)\end{array}$ & 0.0013 \\
\hline Muscle mass (kg) & $24.08 \pm 5.62$ & $\begin{array}{c}23.50 * \\
(11.20-43.50) \\
\end{array}$ & $23.91 \pm 6.05$ & $\begin{array}{c}23.00 * \\
(13.40-52.80) \\
\end{array}$ & 0.5597 \\
\hline Muscle mass (\%) & $51.00 \pm 6.19$ & $\begin{array}{c}51.35^{*} \\
(5.90-64.90)\end{array}$ & $48.25 \pm 6.15$ & $\begin{array}{c}48.35 * \\
(32.70-83.90)\end{array}$ & $<0.0001$ \\
\hline
\end{tabular}

* Nonparametric distribution (verified using Shapiro-Wilk test; $p \leq 0.05$ ); ${ }^{* *}$ compared using $t$-Student test (for parametric distribution) and Mann-Whitney U test (for nonparametric distribution).

The body composition of the girls in the study group participating in a national athletics program and girls in the pair-matched control group are presented in Table 7. It can be noted that significantly higher values of body cell mass share, fat-free mass share, total body water share, extracellular water share, and muscle mass share were observed in the girls participating in a national athletics program compared to the control group of girls. Simultaneously, significantly lower values of fat mass share and intracellular water share were found in the participants of national athletics program than the control group of girls. 
Table 7. The body composition in group of girls participating in a national athletics program and pair-matched control group of girls.

\begin{tabular}{|c|c|c|c|c|c|}
\hline \multirow{2}{*}{$\begin{array}{l}\text { The Assessed } \\
\text { Parameters }\end{array}$} & \multicolumn{2}{|c|}{$\begin{array}{l}\text { Girls Participating in a National } \\
\text { Athletics Program }(n=297)\end{array}$} & \multicolumn{2}{|c|}{$\begin{array}{l}\text { Girls Non-Participating in a National } \\
\text { Athletics Program }(n=297)\end{array}$} & \multirow{2}{*}{$p$-Value ** } \\
\hline & Mean \pm SD & $\begin{array}{c}\text { Median } \\
\text { (Minimum-Maximum) }\end{array}$ & Mean \pm SD & $\begin{array}{l}\text { Median } \\
\text { (Minimum-Maximum) }\end{array}$ & \\
\hline Body cell mass (kg) & $18.19 \pm 3.60$ & $\begin{array}{c}18.30 \\
(8.10-32.90)\end{array}$ & $17.85 \pm 3.64$ & $\begin{array}{c}17.9 \\
(8.90-28.10)\end{array}$ & 0.2604 \\
\hline Body cell mass (\%) & $51.88 \pm 3.16$ & $\begin{array}{c}51.80 * \\
(40.30-69.30)\end{array}$ & $51.08 \pm 3.52$ & $\begin{array}{c}51.10 * \\
(29.00-74.00)\end{array}$ & 0.0022 \\
\hline $\begin{array}{l}\text { Body cell mass index } \\
\qquad\left(\mathrm{kg} / \mathrm{m}^{2}\right)\end{array}$ & $7.29 \pm 1.18$ & $\begin{array}{c}7.20^{*} \\
(4.30-15.60)\end{array}$ & $7.58 \pm 3.98$ & $\begin{array}{c}7.30 * \\
(4.80-73.00)\end{array}$ & 0.3080 \\
\hline Fat-free mass (kg) & $34.92 \pm 5.93$ & $\begin{array}{c}35.10 \\
(17.10-53.80)\end{array}$ & $34.92 \pm 6.30$ & $\begin{array}{c}35.00 \\
(17.90-51.20)\end{array}$ & 0.9936 \\
\hline Fat-free mass (\%) & $74.50 \pm 5.74$ & $\begin{array}{c}74.60 * \\
(56.00-99.70) \\
\end{array}$ & $72.05 \pm 6.27$ & $\begin{array}{c}71.70 \\
(51.80-91.10) \\
\end{array}$ & $<0.0001$ \\
\hline Fat mass (kg) & $12.63 \pm 6.07$ & $\begin{array}{c}11.80 * \\
(0.20-77.00)\end{array}$ & $14.14 \pm 5.97$ & $\begin{array}{c}13.30 * \\
(2.40-36.80)\end{array}$ & 0.0007 \\
\hline Fat mass (\%) & $25.60 \pm 5.84$ & $\begin{array}{c}25.50 * \\
(0.30-44.00)\end{array}$ & $27.97 \pm 6.70$ & $\begin{array}{c}28.20 * \\
(5.19-62.00)\end{array}$ & $<0.0001$ \\
\hline Total body water (kg) & $26.92 \pm 3.37$ & $\begin{array}{c}27.10^{*} \\
(13.10-37.10) \\
\end{array}$ & $26.92 \pm 3.57$ & $\begin{array}{c}26.80 * \\
(13.70-36.00) \\
\end{array}$ & 0.7667 \\
\hline Total body water (\%) & $58.12 \pm 6.66$ & $\begin{array}{c}57.80 * \\
(40.50-96.90) \\
\end{array}$ & $56.22 \pm 7.15$ & $\begin{array}{c}55.80 \\
(39.50-73.60) \\
\end{array}$ & 0.0009 \\
\hline $\mathrm{Na} / \mathrm{K}$ ratio (-) & $1.07 \pm 0.12$ & $\begin{array}{c}1.10^{*} \\
(0.80-1.50)\end{array}$ & $1.06 \pm 0.14$ & $\begin{array}{c}1.10 * \\
(0.70-1.80)\end{array}$ & 0.2863 \\
\hline Extracellular water $(\mathrm{kg})$ & $11.57 \pm 1.94$ & $\begin{array}{c}11.70 \\
(6.30-17.50)\end{array}$ & $11.33 \pm 1.94$ & $\begin{array}{c}11.30 \\
(6.00-17.00)\end{array}$ & 0.1355 \\
\hline Extracellular water (\%) & $42.74 \pm 2.46$ & $\begin{array}{c}43.00 * \\
(34.40-49.70) \\
\end{array}$ & $42.13 \pm 2.31$ & $\begin{array}{c}42.30 * \\
(33.50-48.30) \\
\end{array}$ & 0.0003 \\
\hline Intracellular water (kg) & $15.36 \pm 1.50$ & $\begin{array}{c}15.40 * \\
(6.80-19.80)\end{array}$ & $15.46 \pm 1.74$ & $\begin{array}{c}15.50 * \\
(7.40-20.00)\end{array}$ & 0.4845 \\
\hline Intracellular water (\%) & $57.26 \pm 2.46$ & $\begin{array}{c}57.00 * \\
(50.30-65.60) \\
\end{array}$ & $57.89 \pm 2.32$ & $\begin{array}{c}57.80 * \\
(51.70-66.50)\end{array}$ & 0.0002 \\
\hline Muscle mass (kg) & $22.42 \pm 4.38$ & $\begin{array}{c}22.50 \\
(10.10-40.00) \\
\end{array}$ & $21.98 \pm 4.39$ & $\begin{array}{c}22.00 \\
(11.00-34.20) \\
\end{array}$ & 0.2316 \\
\hline Muscle mass (\%) & $47.48 \pm 5.45$ & $\begin{array}{c}47.50 * \\
(5.40-83.80)\end{array}$ & $45.19 \pm 5.37$ & $\begin{array}{c}45.20 * \\
(23.90-81.10)\end{array}$ & $<0.0001$ \\
\hline
\end{tabular}

* Nonparametric distribution (verified using Shapiro-Wilk test; $p \leq 0.05$ ); ${ }^{* *}$ compared using $t$-Student test (for parametric distribution) and Mann-Whitney U test (for nonparametric distribution).

\section{Discussion}

On the basis of the Polish study conducted in a nationally representative random sample of involving 17,000 children and adolescents, it was stated that the prevalence of excessive body mass for the age group of 7-12 years is, depending on the applied definitions, $21.7-30.4 \%$ and $18.4-23.2 \%$ for boys and girls, respectively, as well as for the age group of $13-18$ years- $-14.6-19.4 \%$ and $10.3-13.0 \%$ for boys and girls, respectively [48]. In the recent Polish study of Wadolowska et al. [49] conducted in the group of over 1500 adolescents aged 11-13, as a part of the ABC of Healthy Eating Project [50], the prevalence of excessive body mass was over $20 \%$, while for $12 \%$ of the group, obesity was diagnosed.

In spite of the fact that the prevalence of excessive body mass in Polish adolescents is lower than in a number of European countries, the alarming trend of increase is indicated, as for the age group of 15 years, since from 2001 to 2014, the share of overweight and obese youth more than doubled [51]. Taking into account Polish statistics, the WHO [52] indicated the necessary actions that should be the key components of effective policy to be implemented in Poland in order to change the trend. Among 
other practical actions, there are those associated with the necessary physical activity interventions, in order to increase both school-based physical activity and extracurricular physical activity [50].

According to the $\mathrm{WHO}$, it is recommend that children and adolescents aged 5-17 years should accumulate at least $60 \mathrm{~min}$ of moderate- to vigorous-intensity physical activity daily, while a higher amounts provide additional health benefits [53]. Similarly, the Centers for Disease Control and Prevention (CDC) of the United States of America, recommends for children and adolescents aged 6-17, 60 min or more of moderate-to-vigorous physical activity each day [54]. The Ministry of Health of the Republic of Poland also recommends at least $60 \mathrm{~min}$ of physical activity daily [55]. However, the prevalence of reaching the recommendations of the WHO regarding physical activity level for Polish adolescents aged $11-17$ years is $28.5 \%$ for boys and $15.2 \%$ for girls [56].

In the conducted own study, it was not surprising to observe beneficial anthropometric measurements and body composition in the group of adolescents participating in a national athletics program in comparison with the pair-matched control group. However, the finding that all the observed parameters were better in the study group may be considered important, as it confirms the comprehensive positive effect of the after-school physical activity program assessed in this study. As the pair-matched samples of adolescents participating and not participating in a national athletics program were compared, while the gender and regional segmentation did not differ between sub-groups, the results may be interpreted as valid.

The present study showed that the recommended level of physical activity influenced not only BMI but also adiposity and the general body composition of the participants. For all the indicated parameters, physical activity was beneficial, which may confirm the positive influence of the national after-school athletics program. However, it must be emphasized that in some studies, even if after a physical activity intervention, some assessed parameters are improved, no success in adiposity reduction was observed [57].

The extracurricular program, assessed in the own study, was conducted in a school setting, included three sessions a week, and ensured regular participation, which made it most effective [18]. In particular, mandatory regular participation may have increased the effectiveness of the program, as it forced the participants to attend all the training sessions. However, this was possible only because the program was free of charge and regular participation was a condition for participation in program. Due to the fact that the parental socioeconomic status may be associated with the body mass of children [58], such actions that allow all children to participate in the physical activity program, independently from the economic status of family, may be especially effective. It results from the necessary actions that must be addressed excessive body mass pediatric population, that in the systematic review and meta-analysis of García-Hermoso et al. [59] were stated to be effective for obese ones.

While a new concepts of the educational programs are regularly analyzed [60,61], it is indicated that they must provide not only the effective results in terms of health promotion, but also be attractive enough to be associated with compliance, that being the necessary element for obtaining the required level of physical activity [62]. The unique strategy that was applied in the present study was associated with the indirect nutritional education via trainers, which may have contributed the obtained results.

Moreover, the fact that the program was an extracurricular one, but conducted in a school setting, may have influenced the observed results. No school-based obligation was applied, so it may be supposed that the participating adolescents were making their own decision to participate, which may have influenced their compliance, as, in general, such an association may be observed [63].

An additional advantage of the program was that it involved professional sport activities, but within the capacity of participants, as the program was organized by Polish Athletic Association and supported by the Ministry of Sport and Tourism. In spite of the fact that it aimed just to increase physical activity in a group of children and adolescents, by conducting regular athletics training, it also allowed adolescents to pursue sport as a future career by providing them with opportunities to meet professional trainers and even star athletes. Thus, the program was very attractive for participants, and it may be supposed that they were willing to participate. 
The conducted program may be suggested to be effective after one year of intervention, but an important limitation of this study was that it was conducted in Poland and has not been verified in other countries thus far. Moreover, due to the fact that no baseline data were gathered, the progress attained by participants may not be assessed, and therefore, further studies are needed. However, the one-year intervention and the fact that the study was conducted in a randomly chosen group of adolescents participating in a real life program may allow us to conclude that the applied approach should be verified in other populations.

Such effective interventions, as implemented in Poland, may be crucial, as the excessive body mass and low physical activity levels observed in childhood and following through into adolescence [64] may continue in adulthood; therefore, reversing this situation is necessary to reduce the risks to general health [65].

\section{Conclusions}

The extracurricular physical activity program, conducted in school settings, including three sessions a week and ensuring regular participation, was highly effective for reduction of body mass, adiposity and improving body composition of adolescents after one year of intervention. To make any physical activity program effective, attractive training sessions and other elements must be planned, so that participants may be willing to participate.

Author Contributions: D.G. (Dominika Głabska), D.G. (Dominika Guzek), B.M., K.Z. made study conception and design; B.M., K.Z., K.Ż. performed the research; D.G. (Dominika Głabska) analyzed the data; D.G. (Dominika Głabska), D.G. (Dominika Guzek) interpreted the data; D.G. (Dominika Głabska), D.G. (Dominika Guzek), B.M., K.Z., K.Ż., K.G. wrote the paper. All the authors read and approved the final manuscript.

Funding: This research and APC were funded by program "Lekkoatletyka dla Każdego" ("Athletics for All") organized by Polish Athletic Association and supported by Ministry of Sport and Tourism, Nestlé Polska S.A. and Faculty of Human Nutrition and Consumer Sciences, Warsaw University of Life Sciences (WULS-SGGW). The analysis were co-financed by Polish Ministry of Science and Higher Education within funds of Faculty of Human Nutrition and Consumer Sciences, Warsaw University of Life Sciences (WULS), for scientific research.

Conflicts of Interest: The authors declare no conflict of interest. The founding sponsors had no role in the design of the study, analyses, interpretation of data and in the writing of the manuscript.

\section{Abbreviations}

$\begin{array}{ll}\text { BMI } & \text { Body Mass Index } \\ \text { IDF } & \text { International Diabetes Federation } \\ \text { WC } & \text { Waist Circumference } \\ \text { WHO } & \text { World Health Organization } \\ \text { WHtR } & \text { Waist-to-Height Ratio }\end{array}$

\section{References}

1. Pozuelo-Carrascosa, D.P.; García-Hermoso, A.; Álvarez-Bueno, C.; Sánchez-López, M.; Martinez-Vizcaino, V. Effectiveness of school-based physical activity programmes on cardiorespiratory fitness in children: A meta-analysis of randomised controlled trials. Br. J. Sports Med. 2018, 52, 1234-1240. [CrossRef] [PubMed]

2. Mura, G.; Vellante, M.; Nardi, A.E.; Machado, S.; Carta, M.G. Effects of School-Based Physical Activity Interventions on Cognition and Academic Achievement: A Systematic Review. CNS Neurol. Disord. Drug Targets 2015, 14, 1194-1208. [CrossRef] [PubMed]

3. Burns, R.D.; Fu, Y.; Podlog, L.W. School-based physical activity interventions and physical activity enjoyment: A meta-analysis. Prev. Med. 2017, 103, 84-90. [CrossRef] [PubMed]

4. Walther, C.; Gaede, L.; Adams, V.; Gelbrich, G.; Leichtle, A.; Erbs, S.; Sonnabend, M.; Fikenzer, K.; Körner, A.; Kiess, W.; et al. Effect of increased exercise in school children on physical fitness and endothelial progenitor cells: A prospective randomized trial. Circulation 2009, 120, 2251-2259. [CrossRef] [PubMed]

5. Lubans, D.R.; Sheaman, C.; Callister, R. Exercise adherence and intervention effects of two school-based resistance training programs for adolescents. Prev. Med. 2010, 50, 56-62. [CrossRef] [PubMed] 
6. Thive, D.; Isacco, L.; Lazaar, N.; Aucouturier, J.; Ratel, S.; Doré, E.; Meyer, M.; Duché, P. Effect of a 6-month school-based physical activity program on body composition and physical fitness in lean and obese schoolchildren. Eur. J. Pediatr. 2011, 170, 1435-1443. [CrossRef] [PubMed]

7. Simon, C.; Schweitzer, B.; Oujaa, M.; Wagner, A.; Arveiler, D.; Triby, E.; Copin, N.; Blanc, S.; Platat, C. Successful overweight prevention in adolescents by increasing physical activity: A 4-year randomized controlled intervention. Int. J. Obes. 2008, 32, 1489-1498. [CrossRef]

8. Kriemler, S.; Zahner, L.; Schindler, C.; Meyer, U.; Hartmann, T.; Hebestreit, H.; Brunner-La Rocca, H.P.; van Mechelen, W.; Puder, J.J. Effect of school based physical activity programme (KISS) on fitness and adiposity in primary schoolchildren: Cluster randomised controlled trial. BMJ 2010, 340, c785. [CrossRef]

9. Li, X.H.; Lin, S.; Guo, H.; Huang, Y.; Wu, L.; Zhang, Z.; Ma, J.; Wang, H.J. Effectiveness of a school-based physical activity intervention on obesity in school children: A nonrandomized controlled trial. BMC Public Health 2014, 14, 1282. [CrossRef]

10. Guerra, P.H.; Nobre, M.R.; Silveira, J.A.; Taddei, J.A. The effect of school-based physical activity interventions on body mass index: A meta-analysis of randomized trials. Clinics 2013, 68, 1263-1273. [CrossRef]

11. Harris, K.C.; Kuramoto, L.K.; Schulzer, M.; Retallack, J.E. Effect of school-based physical activity interventions on body mass index in children: A meta-analysis. CMAJ 2009, 180, 719-726. [CrossRef] [PubMed]

12. Committee on Physical Activity and Physical Education in the School Environment; Food and Nutrition Board; Institute of Medicine; Kohl, H.W., III; Cook, H.D. (Eds.) Educating the Student Body: Taking Physical Activity and Physical Education to School; National Academies Press (US): Washington, DC, USA, 2013; 6 Approaches to Physical Activity in Schools. Available online: https://www.ncbi.nlm.nih.gov/books/ NBK201495/ (accessed on 21 December 2018).

13. Martínez Vizcaíno, V.; Salcedo Aguilar, F.; Franquelo Gutiérrez, R.; Solera Martínez, M.; Sánchez López, M.; Serrano Martínez, S.; López García, E.; Rodríguez Artalejo, F. Assessment of an after-school physical activity program to prevent obesity among 9- to 10-year-old children: A cluster randomized trial. Int. J. Obes. 2008, 32, 12-22. [CrossRef] [PubMed]

14. Martínez-Vizcaíno, V.; Sánchez-López, M.; Notario-Pacheco, B.; Salcedo-Aguilar, F.; Solera-Martínez, M.; Franquelo-Morales, P.; López-Martínez, S.; García-Prieto, J.C.; Arias-Palencia, N.; Torrijos-Niño, C.; et al. Gender differences on effectiveness of a school-based physical activity intervention for reducing cardiometabolic risk: A cluster randomized trial. Int. J. Behav. Nutr. Phys. Act. 2014, 11, 154. [CrossRef] [PubMed]

15. Yin, Z.; Moore, J.B.; Johnson, M.H.; Vernon, M.M.; Gutin, B. The impact of a 3-year after-school obesity prevention program in elementary school children. Child. Obes. 2012, 8, 60-70. [CrossRef] [PubMed]

16. Salcedo Aguilar, F.; Martínez-Vizcaíno, V.; Sánchez López, M.; Solera Martínez, M.; Franquelo Gutiérrez, R.; Serrano Martínez, S.; López-García, E.; Rodríguez-Artalejo, F. Impact of an after-school physical activity program on obesity in children. J. Pediatr. 2010, 157, 36-42. [CrossRef] [PubMed]

17. Mears, R.; Jago, R. Effectiveness of after-school interventions at increasing moderate-to-vigorous physical activity levels in 5- to 18-year olds: A systematic review and meta-analysis. Br. J. Sports Med. 2016, 50, 1315-1324. [CrossRef] [PubMed]

18. Demetriou, Y.; Gillison, F.; McKenzie, T.L. After-School Physical Activity Interventions on Child and Adolescent Physical Activity and Health: A Review of Reviews. Adv. Phys. Educ. 2017, 7, 191-215. [CrossRef]

19. Elliot, C.A.; Hamlin, M.J. Combined diet and physical activity is better than diet or physical activity alone at improving health outcomes for patients in New Zealand's primary care intervention. BMC Public Health 2018, 18, 230. [CrossRef] [PubMed]

20. World Health Organization. School Policy Framework: Implementation of the WHO Global Strategy on Diet, Physical Activity and Health; WHO Document Production Services: Geneva, Switzerland, 2008; pp. 1-53.

21. Romieu, I.; Dossus, L.; Barquera, S.; Blottière, H.M.; Franks, P.W.; Gunter, M.; Hwalla, N.; Hursting, S.D.; Leitzmann, M.; Margetts, B.; et al. Energy balance and obesity: What are the main drivers? Cancer Causes Control 2017, 28, 247-258. [CrossRef]

22. Plachta-Danielzik, S.; Landsberg, B.; Johannsen, M.; Lange, D.; Müller, M.J. Determinants of the prevalence and incidence of overweight in children and adolescents. Public Health Nutr. 2010, 13, 1870-1881. [CrossRef]

23. Cardel, M.; Dulin-Keita, A.; Casazza, K. Contributors to Pediatric Obesity in Adolescence: More than just Energy Imbalance. Open Obes. J. 2011, 3, 17-26. [CrossRef] [PubMed] 
24. Belski, R.; Staley, K.; Keenan, S.; Skiadopoulos, A.; Randle, E.; Donaldson, A.; O’Halloran, P.; Kappelides, P.; O'Neil, S.; Nicholson, M. The impact of coaches providing healthy snacks at junior sport training. Aust. N. Z. J. Public Health 2017, 41, 561-566. [CrossRef]

25. Guzek, D.; Głąbska, D.; Mellová, B.; Zadka, K.; Żywczyk, K.; Gutkowska, K. Influence of food neophobia level on fruit and vegetable intake and its association with urban area of residence and physical activity in a nationwide case-control study of Polish adolescents. Nutrients 2018, 10, 897. [CrossRef] [PubMed]

26. Demographic Yearbook of Poland. Statistics Poland, Warsaw 2018. Available online: https://stat.gov.pl/ obszary-tematyczne/roczniki-statystyczne/roczniki-statystyczne/rocznik-demograficzny-2018,3,12.html (accessed on 21 January 2019).

27. Zwierzchowska, A.; Grabara, M.; Palica, D.; Zając, A. BMI and BAI as markers of obesity in a Caucasian population. Obes. Facts 2013, 6, 507-511. [CrossRef]

28. Hamułka, J.; Głąbska, D.; Guzek, D.; Białkowska, A.; Sulich, A. Intake of Saturated Fatty Acids Affects Atherogenic Blood Properties in Young, Caucasian, Overweight Women Even without Influencing Blood Cholesterol. Int. J. Environ. Res. Public Health 2018, 15, 2530. [CrossRef] [PubMed]

29. Głabska, D.; Guzek, D.; Zakrzewska, P.; Lech, G. Intake of Lutein and Zeaxanthin as a Possible Factor Influencing Gastrointestinal Symptoms in Caucasian Individuals with Ulcerative Colitis in Remission Phase. J. Clin. Med. 2018, 8, 77. [CrossRef]

30. Bacil, E.D.; Mazzardo Júnior, O.; Rech, C.R.; Legnani, R.F.; de Campos, W. Physical activity and biological maturation: A systematic review. Rev. Paul. Pediatr. 2015, 33, 114-121. (In Portuguese) [CrossRef]

31. Faria, E.R.; Franceschini Sdo, C.; Peluzio Mdo, C.; Sant'Ana, L.F.; Priore, S.E. Methodological and ethical aspects of the sexual maturation assessment in adolescents. Rev. Paul. Pediatr. 2013, 31, 398-405. [CrossRef]

32. Benítez-Porres, J.; Alvero-Cruz, J.R.; Carrillo de Albornoz, M.; Correas-Gómez, L.; Barrera-Expósito, J.; Dorado-Guzmán, M.; Moore, J.B.; Carnero, E.A. The Influence of 2-Year Changes in Physical Activity, Maturation, and Nutrition on Adiposity in Adolescent Youth. PLoS ONE 2016, 11, e0162395. [CrossRef]

33. ISAK. International Standards for Anthropometric Assessment. International Society for the Advancement of Kinanthropometry: Potchefstroom, South Africa, 2001. Available online: http:/ /www.ceap.br/material/ MAT17032011184632.pdf (accessed on 21 December 2018).

34. Kulaga, Z.; Litwin, M.; Tkaczyk, M.; Rózdzyńska, A.; Barwicka, K.; Grajda, A.; Swiader, A.; Gurzkowska, B.; Napieralska, E.; Pan, H. The height-, weight-, and BMI-for-age of Polish school-aged children and adolescents relative to international and local growth references. BMC Public Health 2010, 10, 109. [CrossRef] [PubMed]

35. OLAF Calculator from OLAF Study. Available online: http://olaf.czd.pl/index.php?option=com_content\& view =article\&id=103:kalkulator (accessed on 21 December 2018).

36. de Onis, M.D.; Onyango, A.W.; Borghi, E.; Siyam, A.; Nishida, C.; Siekmann, J. Development of a WHO growth reference for school-aged children and adolescents. Bull. World Health Org. 2007, 85, 660-667. [CrossRef] [PubMed]

37. Choi, D.H.; Hur, Y.I.; Kang, J.H.; Kim, K.; Cho, Y.G.; Hong, S.M.; Cho, E.B. Usefulness of the Waist Circumference-to-Height Ratio in Screening for Obesity and Metabolic Syndrome among Korean Children and Adolescents: Korea National Health and Nutrition Examination Survey, 2010-2014. Nutrients 2017, 9, 256. [CrossRef] [PubMed]

38. World Health Organization. Definition, Diagnosis and Classification of Diabetes Mellitus and Its Complications: Report of a WHO Consultation; WHO: Geneva, Switzerland, 1999.

39. Alberti, K.G.M.M.; Zimmet, P.; Shaw, J. Metabolic syndrome-A new world-wide definition. A Consensus Statement from the International Diabetes Federation. Diabet. Med. 2006, 23, 469-480. [PubMed]

40. Ma, W.Y.; Yang, C.Y.; Shih, S.R.; Hsieh, H.J.; Hung, C.S.; Chiu, F.C.; Lin, M.S.; Liu, P.H.; Hua, C.H.; Hsein, Y.C.; et al. Measurement of Waist Circumference: Midabdominal or iliac crest? Diabetes Care 2013, 36, 1660-1666. [CrossRef] [PubMed]

41. Świąder-Leśniak, A.; Kułaga, Z.; Grajda, A.; Gurzkowska, B.; Góźdź, M.; Wojtyło, M.; Różdżyńska-Świątkowska, A.; Litwin, M. Wartości referencyjne obwodu talii i bioder polskich dzieci i młodzieży w wieku 3-18 lat. [References for waist and hip circumferences in Polish children and adolescents 3-18 year of age]. Stand. Med./Pediatria 2015, 12, 137-150. (In Polish)

42. Cook, S.; Weitzman, M.; Auinger, P.; Nguyen, M.; Dietz, W.H. Prevalence of a metabolic syndrome phenotype in adolescents: Findings from the third National Health and Nutrition Examination Survey, 1988-1994. Arch. Pediatr. Adolesc. Med. 2003, 157, 821-827. [CrossRef] 
43. Campagnolo, P.D.; Hoffman, D.J.; Vitolo, M.R. Waist-to-height ratio as a screening tool for children with risk factors for cardiovascular disease. Ann. Hum. Biol. 2011, 38, 265-270. [CrossRef]

44. McCarthy, H.D.; Ashwell, M. A study of central fatness using waist-to-height ratios in UK children and adolescents over two decades supports the simple message-'Keep your waist circumference to less than half your height'. Int. J. Obes. 2006, 30, 988-992. [CrossRef]

45. Głabska, D.; Cackowska, K.; Guzek, D. Comparison of the Body Composition of Caucasian Young Normal Body Mass Women, Measured in the Follicular Phase, Depending on the Carbohydrate Diet Level. Medicina 2018, 54, 104. [CrossRef]

46. Kyle, U.G.; Bosaeus, I.; De Lorenzo, A.D.; Deurenberg, P.; Elia, M.; Manuel Gómez, J.; Lilienthal Heitmann, B.; Kent-Smith, L.; Melchior, J.C.; Pirlich, M.; et al. Bioelectrical impedance analysis-part II: Utilization in clinical practice. Clin. Nutr. 2004, 23, 1430-1453. [CrossRef]

47. Głąbska, D.; Guzek, D.; Lech, G. Nutritional Status of Men with Ulcerative Colitis in Remission in a Pair-Matched Case-Control Study. J. Clin. Med. 2018, 7, 438. [CrossRef] [PubMed]

48. Kułaga, Z.; Grajda, A.; Gurzkowska, B.; Wojtyło, M.A.; Góźdź, M.; Litwin, M.S. The prevalence of overweight and obesity among Polish school- aged children and adolescents. Przegl Epidemiol. 2016, 70, 641-651. [PubMed]

49. Wadolowska, L.; Hamulka, J.; Kowalkowska, J.; Kostecka, M.; Wadolowska, K.; Biezanowska-Kopec, R.; Czarniecka-Skubina, E.; Kozirok, W.; Piotrowska, A. Prudent-Active and Fast-Food-Sedentary Dietary-Lifestyle Patterns: The Association with Adiposity, Nutrition Knowledge and Sociodemographic Factors in Polish Teenagers-The ABC of Healthy Eating Project. Nutrients 2018, 10, 1988. [CrossRef] [PubMed]

50. Hamulka, J.; Wadolowska, L.; Hoffmann, M.; Kowalkowska, J.; Gutkowska, K. Effect of an Education Program on Nutrition Knowledge, Attitudes toward Nutrition, Diet Quality, Lifestyle, and Body Composition in Polish Teenagers. The ABC of Healthy Eating Project: Design, Protocol, and Methodology. Nutrients 2018, 10, 1439. [CrossRef]

51. OECD/European Observatory on Health Systems and Policies, Poland: Country Health Profile 2017, State of Health in the EU, OECD Publishing, Paris/European Observatory on Health Systems and Policies, Brussels. Available online: http:/ / dx.doi.org/10.1787/9789264283510-en (accessed on 21 January 2019).

52. WHO Raport: Reducing Childhood Obesity in Poland. Technical Report. Available online: http:/ / www.euro.who.int/en/countries/poland/publications/reducing-childhood-obesity-in-polandby-effective-policies-2017 (accessed on 21 January 2019).

53. World Health Organization. Global Recommendations on Physical Activity for Health; WHO: Geneva, Switzerland, 2010.

54. U.S. Department of Health and Human Services. Physical Activity Guidelines for Americans, 2nd ed.; Department of Health and Human Services: Washington, DC, USA, 2018.

55. Ministry of Health of the Republic of Poland. Physical Activity and Sport. Available online: https:/ /www. gov.pl/web/zdrowie/aktywnosc-fizyczna-i-sport (accessed on 21 January 2019). (In Polish)

56. World Health Organization (WHO). Poland Physical Activity Factsheet. Available online: https://www. who.int/dietphysicalactivity/global-PA-recs-2010.pdf (accessed on 21 January 2019).

57. Martínez-Vizcaíno, V.; Pozuelo-Carrascosa, D.P.; García-Prieto, J.C.; Cavero-Redondo, I.; Solera-Martínez, M.; Garrido-Miguel, M.; Díez-Fernández, A.; Ruiz-Hermosa, A.; Sánchez-López, M. Effectiveness of a school-based physical activity intervention on adiposity, fitness and blood pressure: MOVI-KIDS study. Br. J. Sports Med. 2019, 9, 99655. [CrossRef] [PubMed]

58. Martínez-Vizcaíno, V.; Solera-Martínez, M.; Cavero-Redondo, I.; García-Prieto, J.C.; Arias-Palencia, N.; Notario-Pacheco, B.; Martínez-Andrés, M.; Mota, J.; Sánchez-López, M.; Cuenca Study Group. Association between parental socioeconomic status with underweight and obesity in children from two Spanish birth cohorts: A changing relationship. BMC Public Health 2015, 15, 1276. [CrossRef]

59. García-Hermoso, A.; Ramírez-Vélez, R.; Ramírez-Campillo, R.; Peterson, M.D.; Martínez-Vizcaíno, V. Concurrent aerobic plus resistance exercise versus aerobic exercise alone to improve health outcomes in paediatric obesity: A systematic review and meta-analysis. Br. J. Sports Med. 2018, 52, 161-166. [CrossRef]

60. Martínez-Vizcaíno, V.; Sánchez-López, M.; Salcedo-Aguilar, F.; Notario-Pacheco, B.; Solera-Martínez, M.; Moya-Martínez, P.; Franquelo-Morales, P.; López-Martínez, S.; Rodríguez-Artalejo, F.; MOVI-2 Group. Protocol of a randomized cluster trial to assess the effectiveness of the MOVI-2 program on overweight prevention in schoolchildren. Rev. Esp. Cardiol. 2012, 65, 427-433. [CrossRef] 
61. Moya Martínez, P.; Sánchez López, M.; López Bastida, J.; Escribano Sotos, F.; Notario Pacheco, B.; Salcedo Aguilar, F.; Martínez Vizcaíno, V. Cost-effectiveness of an intervention to reduce overweight and obesity in 9-10-year-olds. The Cuenca study. Gac. Sanit. 2011, 25, 198-204. (In Spanish) [CrossRef]

62. Arias-Palencia, N.M.; Solera-Martínez, M.; Gracia-Marco, L.; Silva, P.; Martínez-Vizcaíno, V.; Cañete-García-Prieto, J.; Sánchez-López, M. Levels and Patterns of Objectively Assessed Physical Activity and Compliance with Different Public Health Guidelines in University Students. PLoS ONE 2015, 10, e0141977. [CrossRef] [PubMed]

63. Grootens-Wiegers, P.; Hein, I.M.; van den Broek, J.M.; de Vries, M.C. Medical decision-making in children and adolescents: Developmental and neuroscientific aspects. BMC Pediatr. 2017, 17, 120. [CrossRef] [PubMed]

64. Pahkala, K.; Hernelahti, M.; Heinonen, O.J.; Raittinen, P.; Hakanen, M.; Lagström, H.; Viikari, J.S.; Rönnemaa, T.; Raitakari, O.T.; Simell, O. Body mass index, fitness and physical activity from childhood through adolescence. Br. J. Sports Med. 2013, 47, 71-77. [CrossRef] [PubMed]

65. Menschik, D.; Ahmed, S.; Alexander, M.H.; Blum, R.W. Adolescent physical activities as predictors of young adult weight. Arch. Pediatr. Adolesc. Med. 2008, 162, 29-33. [CrossRef] [PubMed]

(C) 2019 by the authors. Licensee MDPI, Basel, Switzerland. This article is an open access article distributed under the terms and conditions of the Creative Commons Attribution (CC BY) license (http://creativecommons.org/licenses/by/4.0/). 